\title{
Developing an Extraction Method of Urban Built-Up Area Based on Remote Sensing Imagery Transformation Index
}

\author{
Iswari Nur Hidayati ${ }^{1,}$, R. Suharyadi ${ }^{2}$, Projo Danoedoro ${ }^{2}$ \\ ${ }^{1}$ Doctoral Program, Faculty of Geography, Gadjah Mada University, Jl. Kaliurang, Bulaksumur, \\ Yogyakarta 55281, Indonesia \\ ${ }^{2}$ Faculty of Geography, Gadjah Mada University, Jl. Kaliurang, Bulaksumur, Yogyakarta 55281, \\ Indonesia \\ *) Corresponding author (e-mail: iswari@ugm.ac.id)
}

Received: 24 March 2018 / Accepted: 16 April 2018 / Published: 28 April 2018

\begin{abstract}
Studying urban areas using remote sensing imagery has become a challenge, both visually and digitally. Supervised classification, one of the digital classification approaches to differentiate between built-up and non-built-up area, used to be leading in digital studies of urban area. Then the next generation uses index transformation for automatic urban data extraction. The extraction of urban built-up land can be automatically done with NDBI although it has one limitation on separating built-up land and bare land. The previous studies provide opportunities for further research to increase the accuracy of the extraction, particularly using index transformation. This study aims to obtain the maximum accuracy of the extraction by merging several indices including NDBI, NDVI, MNDWI, NDWI, and SAVI. The merging of the indices is using four stages: merging of two indices, three indices, four indexes and five indices. Several operations were experimented to merge the indices, either by addition, subtraction, or multiplication. The results show that merging NDBI and MNDWI produce the highest accuracy of $90.30 \%$ either by multiplication (overlay) or reduction. Application of SAVI, NDBI, and NDWI also gives a good effect for extracting urban built-up areas and has $85.72 \%$ mapping accuracy.
\end{abstract}

Keywords: built-up area extraction, remote sensing, index transformation, Landsat 8 OLI.

Abstrak. Secara visual maupun digital, area perkotaan menjadi subyek kajian yang menarik untuk diteliti. Berdasarkan data digital penginderaan jauh dengan metode klasifikasi terselia dapat membedakan lahan terbangun dan lahan tidak terbangun di aera perkotaan. Penelitian ekstraksi lahan terbangun perkotaan berkembang pesat di mulai dari klasifikasi terselia menjadi indeks transformasi lahan terbangun perkotaan. NDBI, salah satu indeks lahan terbangun, mempunyai kelebihan dan kekurangan. NDBI tidak bisa membedakan lahan terbangun perkotaan dan lahan terbuka perkotaan. Berdasarkan kekurangan indeks lahan terbangun tersebut, penelitian pengembangan indeks lahan terbangun perkotaan masih terbuka untuk dikembangkan dalam rangka meningkatkan akurasi pemetaan. Penelitian ini bertujuan untuk mengoptimalkan akurasi dalam ekstraksi lahan terbangun perkotaan dengan melakukan penggabungan NDBI, NDBI, MNDWI, NDWI, dan SAVI. Penggabungan ini mulai dari penggabungan dua indeks, tiga indeks, empat indeks, dan lima indeks. Metode penggabungan juga mencoba menggunakan beberapa algoritma matematika seperti ditambahkan, dikurangi, dibagi, serta dikalikan. Hasil penelitian ini menunjukkan bahwa penggabungan NDBI dan MNDBWI mendapatkan akurasi tertingi yaitu 90,30\%. Pemanfaatan SAVI, NDBI, NDWI juga memberikan efek yang baik dan mendapatkan akurasi pemetaan sebesar 85,72\%.

Kata Kunci: ekstraksi lahan terbangun, penginderaan jauh, indeks transformasi, Landsat 8 OLI. 


\section{Introduction}

Urban areas in Indonesia are growing very dynamically in line with the dynamics of population growth, economic growth and environmental development ( $\mathrm{Li}$ et al., 2016). Uncontrolled urban growth has forced urban structure to change, the conversion of agricultural land and urban green space to decrease. Satellite imagery and spatial data can be used for urban growth mapping and monitoring (Hai \& Yamaguchi, 2007). There are massive studies on the development of urban settlements areas using remote sensing data including Bagan \& Yamagata (2012) who used combination of remote sensing and population census data in grid cell which enables us to understand the detailed spatial and temporal patterns and trends of urban growth, SuarezRubio et al. (2012) found that combined spectral mixture analysis, decision-tree classification, and morphological spatial pattern analysis to be a powerful tool for making better accuracy, and Deng \& Wu (2013) who conducted biophysical composition index from imagery data.

Meanwhile, multispectral classification with supervised classification method is the general method for settlement and nonsettlement classification (Liu \& Yang, 2013; McInerney \& Lozar, 2007). However, there are still problems related to the classification result, particularly the mixing of built-up land with others results classification. A multispectral classification approach is developed by the method of combining the same pixel value for each land use/land cover class (Couturier et al., 2011; Forzieri et al., 2013; Liu \& Yang, 2013). The supervised classification, one part of multispectral classification, requires training areas for making a classification. Although multispectral classification is very useful for making land use classification, this method has a limitation in getting other information such as vegetation indices and built-up land information. Therefore, the development of index transformation in digital image processing becomes an alternative for optimising the remote sensing data extraction.

A number of techniques for automatically mapping urban land cover using satellite imagery have been formulated, applied and evaluated. Various techniques have been used to simplify the process of automatically mapping land covers using transformation index. One of the commonly used indices is the Normalized Difference Vegetation Index (NDVI). By transforming raw satellite data into NDVI values, researchers can create images and other products that give a rough measure of vegetation type, amount, and condition on land surfaces around the world (Glenn et al., 2008; Caroline \& Hidayati, 2016; Purwanto, 2015). Zha et al. (2003) proposed Normalized | Difference Built-up Index (NDBI) to map urban built-up areas automatically. Although NDBI is already widely used for the extraction of urban built-up areas, it still has limitations. Therefore, it is necessary to develop new methods by combining some indices and improving the accuracy of built-up area maps (Hidayati et al., 2017; He et al., 2010).

This study aims to address the limitations of the extraction method by improving the built-up area extraction accuracy. The improvement is by combining/merging several indices using several operation procedures. The indices used in this study including NDVI (Normalized Difference Vegetation Index), SAVI (Soil Adjusted Vegetation Index), Modified Normalized Difference Built-up Index (MNDWI), and NDBI (Normalized Difference Built-up Index). The mathematical formulations which are multiplication $\left(^{*}\right)$, reduction (-), and addition (+) were tested in this study to obtain maximum accuracy for urban built land extraction.

\section{Research Method}

\subsection{Study area and data}

Yogyakarta urban area is passed by three main rivers: Winongo River, Code River, and Gajahwong River and it administratively covers three regions including Bantul Regency, Sleman Regency, and Yogyakarta City. A survey conducted by IAP (2014) in 15 major cities in Indonesia, found that Yogyakarta has the most liveable index in Indonesia with the percentage of $66.52 \%$. The second position was Denpasar with a percentage of $63.3 \%$. 
Meanwhile, the city with the lowest perception of citizen comfort is Medan (46.67\%) and Pontianak (46.2\%). The urban has a complex ecosystem with various materials, such as vegetation, sealed area, water area and build up land. Urban areas are dominated by urban built-up land, urban impervious surface, and conversion of agricultural land or green open space into the constructed land (Hidayati et al., 2017). Significantly, the development of constructed land will have a direct effect on urban microclimate which impacts on the comfort level of residence for its residents. Research subjects on urban-built land such as residential size, shape, and spatial context always require high accuracy both spatially and temporally.

Remote sensing data used in this study is Landsat 8 OLI (cloud-free) with path/row 120/65 recorded on September 15, 2015 (Figure 1). The Landsat 8 OLI image has various spectral resolution characteristics, Landsat 8 OLI capability with 11 bands comprising band 1 (coastal/aerosol), band 2 (blue), band 3 (green), band 4 (red), band 5 ( NIR), band 6 SWIR 1), band 7 (SWIR1), band 8 (panchromatic), band 9 (cirrus), band 10 and band 11 (thermal channel). Several new specifications are attached to this Landsat band especially on bands 1, 9, 10, and 11. The composite bands in Landsat imagery are used to obtain multispectral classification information of land use and automatic extraction in urban areas such as vegetation information, soil, built-up land, water, and so forth. The completeness bands of Landsat 8 OLI imagery provides an opportunity to improve research methods in remote sensing field to find the best methods of urban built-up data extraction. However, it has a potential risk of mixing pixel due to the resolution size (Sari et al., 2017). Therefore, it needs a proper method on extracting the information.

\subsection{Normalized Difference Vegetation Index}

The vegetation index is a combination of several bands that can produce information related to vegetation density. Campbell \& Wynne (2011) states that the phenomenon of red band absorption by chlorophyll $(0.4 \mu \mathrm{m}$ $0.7 \mu \mathrm{m})$ in vegetation and infrared reflections close to mesophyll $(0.7 \mu \mathrm{m}-1.1 \mu \mathrm{m})$ in the leaves make a difference in brightness values. Therefore, the transformation of the selected vegetation index involves red band and infrared band. The Normalized Difference Vegetation Index (NDVI) is selected because the comparison form between the infrared band and the red band will minimise the irradiance conditions caused by changes in sun angle, topography, atmospheric conditions, and cloud cover.

\subsection{Soil-Adjusted Vegetation Index}

Urban areas that are not overgrown by vegetation will provide many soil reflections. Sometimes, low-density vegetation areas such as rice field with very young plants can become subject to a mistake in the calculation process involving the vegetation index. The Soil-Adjusted Vegetation Index (SAVI) aims to derive errors from soil colour variations by including L values (Huete, 1988; Kaspersen et al., 2015). The L-correlation factor varies depending on the reflectance characteristics of the vegetation cover. The variation of $\mathrm{L}$ values depends on the vegetation density. Vegetation with low density will get $\mathrm{L}$ value of 1 , while high-density vegetation will use $\mathrm{L}$ value of 0.25 . This study used correction factor $\mathrm{L}=0.5$ because in the research area there is low-density vegetation to high-density vegetation (Kaspersen et al., 2015)and mapping of urban IS is important for a wide range of applications including hydrological modelling, water management, urban and environmental planning and urban climate studies. This paper addresses the accuracy and applicability of vegetation indices (VI. Equation 1 provides the SAVI formula by Huete (1988).

$$
\text { SAVI }=\frac{(\text { NIR-Red })(1+1)}{\text { NIR }+ \text { Red }+1}
$$



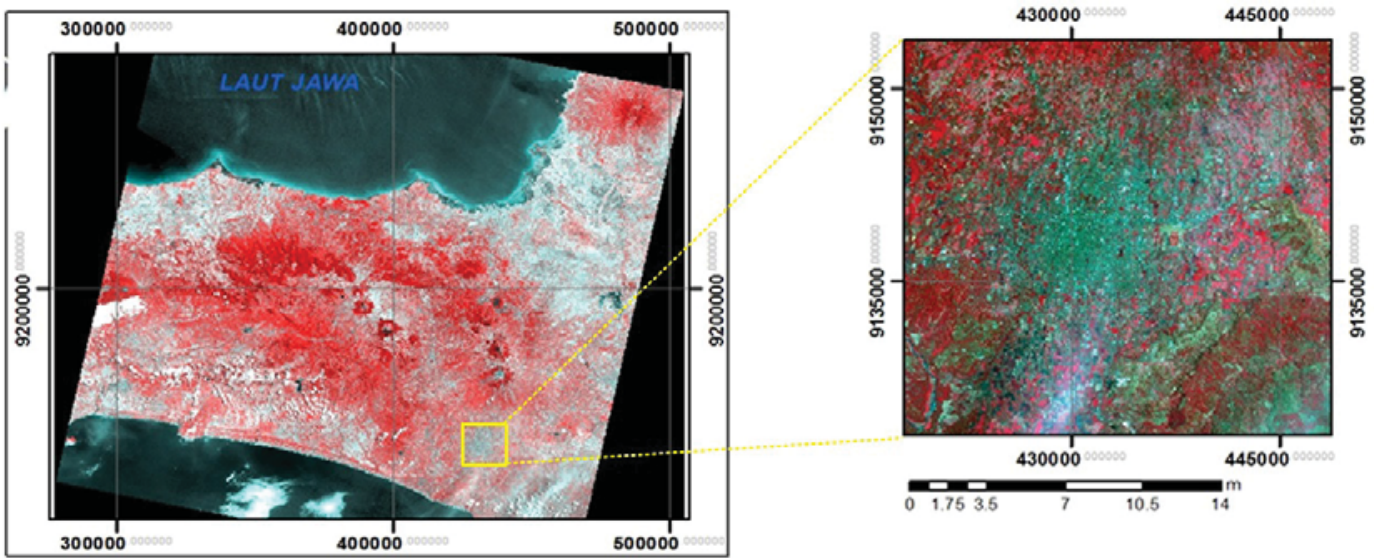

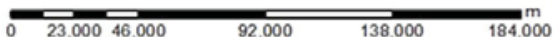

Figure 1. Research area (source: $h$ ttp://landsat.USGS.gov/).

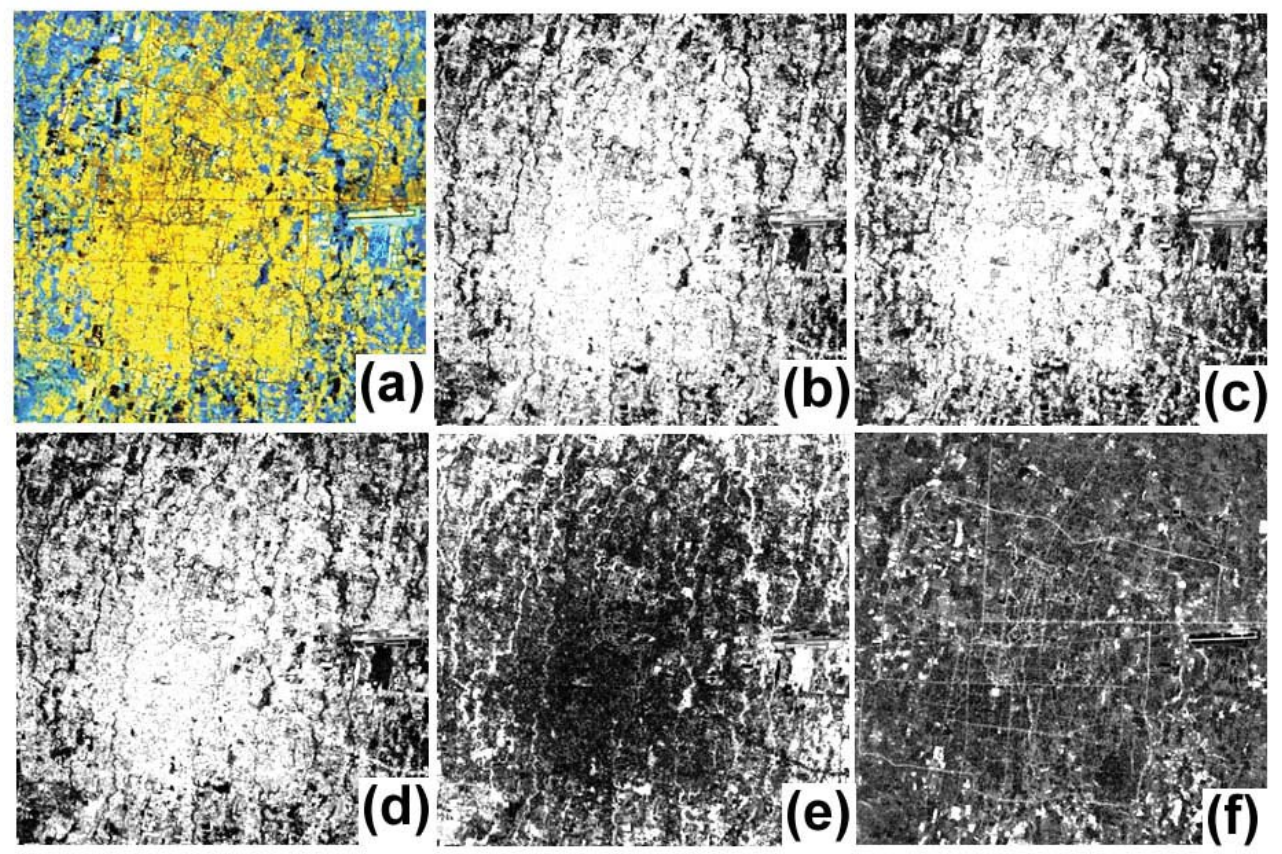

Figure 2. Landsat OLI and Images of Transformation Index. (a) Composite of Landsat OLI, (b) NDVI, (c) NDBI, (d) SAVI, (e) NDWI, (f) MNDWI.

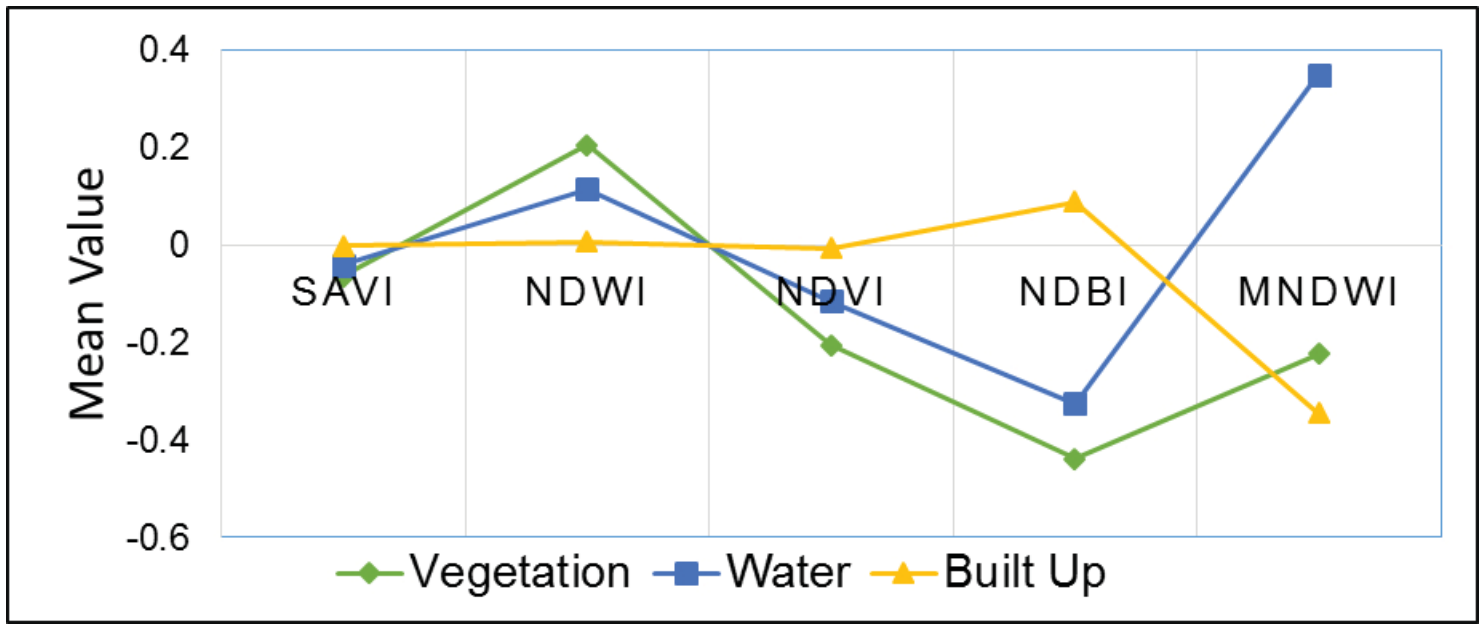

Figure 3. Mean values based on land use classification of vegetation, water body, and built-up 


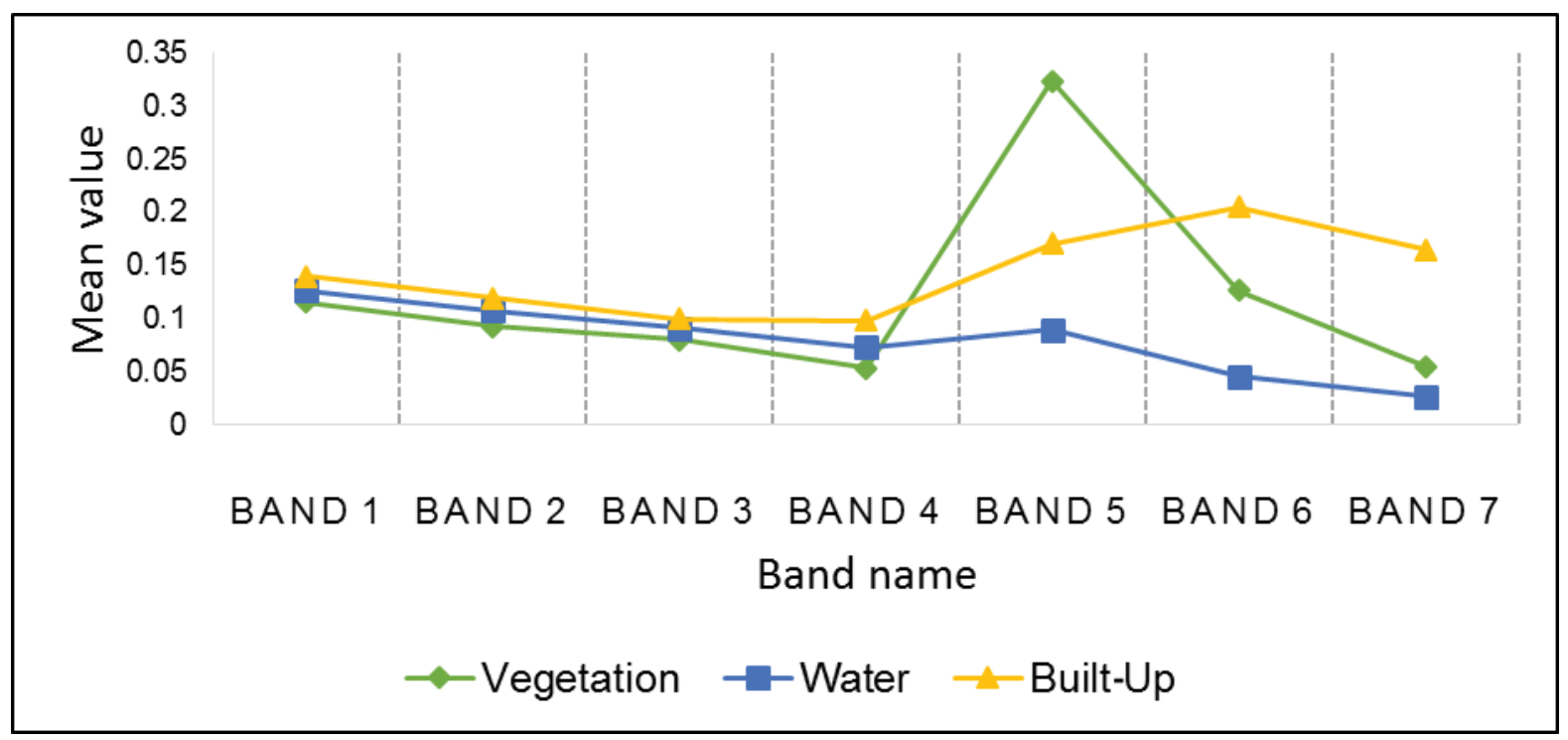

Figure 4. Vegetation, water, and built-up mean values of Landsat 8 OLI.

Table 1. The dynamic range of NDVI, MNDWI, and NDWI.

\begin{tabular}{cccc}
\hline Index & Minimum & Maximum & Dynamic Range \\
\hline SAVI & -0.161 & 0.139 & 0.300 \\
NDVI & -0.318 & 0.273 & 0.591 \\
MNDWI & -0.688 & 0.868 & 1.556 \\
NDWI & -0.273 & 0.318 & 0.591 \\
\hline
\end{tabular}

$\rightarrow$ Vegetation $\rightarrow$-Water $\rightarrow-$ Built Up

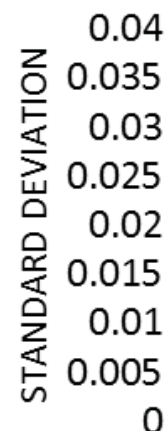

BAND 1 BAND 2 BAND 3 BAND 4 BAND 5 BAND 6 BAND 7 BAND NUMBER

Figure 5. Land use deviation Standard of Landsat OLI.

Table 2. Mean value of NDVI, SAVI, MNDWI, and NDWI.

\begin{tabular}{ccccc}
\hline \multirow{2}{*}{$\begin{array}{c}\text { Land use } \\
\text { class }\end{array}$} & NDVI & SAVI & MNDWI & NDWI \\
\cline { 2 - 5 } & -0.097522 & -0.029868 & -0.13202 & 0.097522 \\
\hline Vegetation & -0.13563 & -0.043206 & -0.269191 & 0.13563 \\
Water & -0.132991 & -0.042212 & -0.263908 & 0.132991 \\
Built up &
\end{tabular}


Table 3. Correlation values of index transformation.

\begin{tabular}{cccccc}
\hline Correlation & SAVI & NDWI & NDVI & NDBI & MNDWI \\
\hline SAVI & 1 & -0.99432 & 0.994317 & 0.964647 & 0.930279 \\
NDWI & -0.99432 & 1 & -1 & -0.97269 & -0.90427 \\
NDVI & 0.994317 & -1 & 1 & 0.972687 & 0.90427 \\
NDBI & 0.964647 & -0.97269 & 0.972687 & 1 & 0.833453 \\
MNDWI & 0.930279 & -0.90427 & 0.90427 & 0.833453 & 1 \\
\hline
\end{tabular}

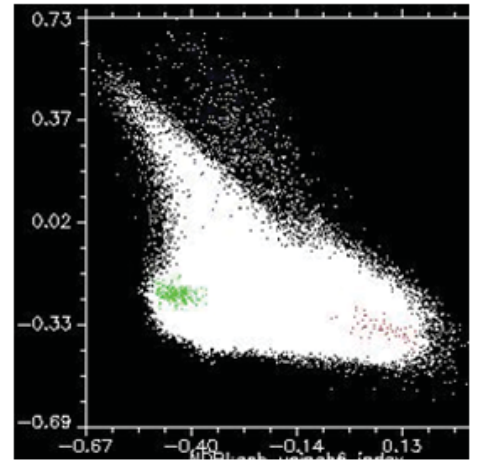

(a)

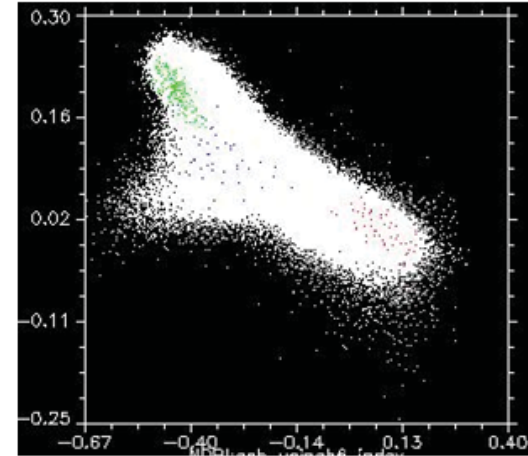

(b)

Figure 6. Land use scattergram plot based on index transformation. NDBI (x-axis) and MNDWI (y-axis); (b) NDBI (x-axis) and NDWI (y-axis).

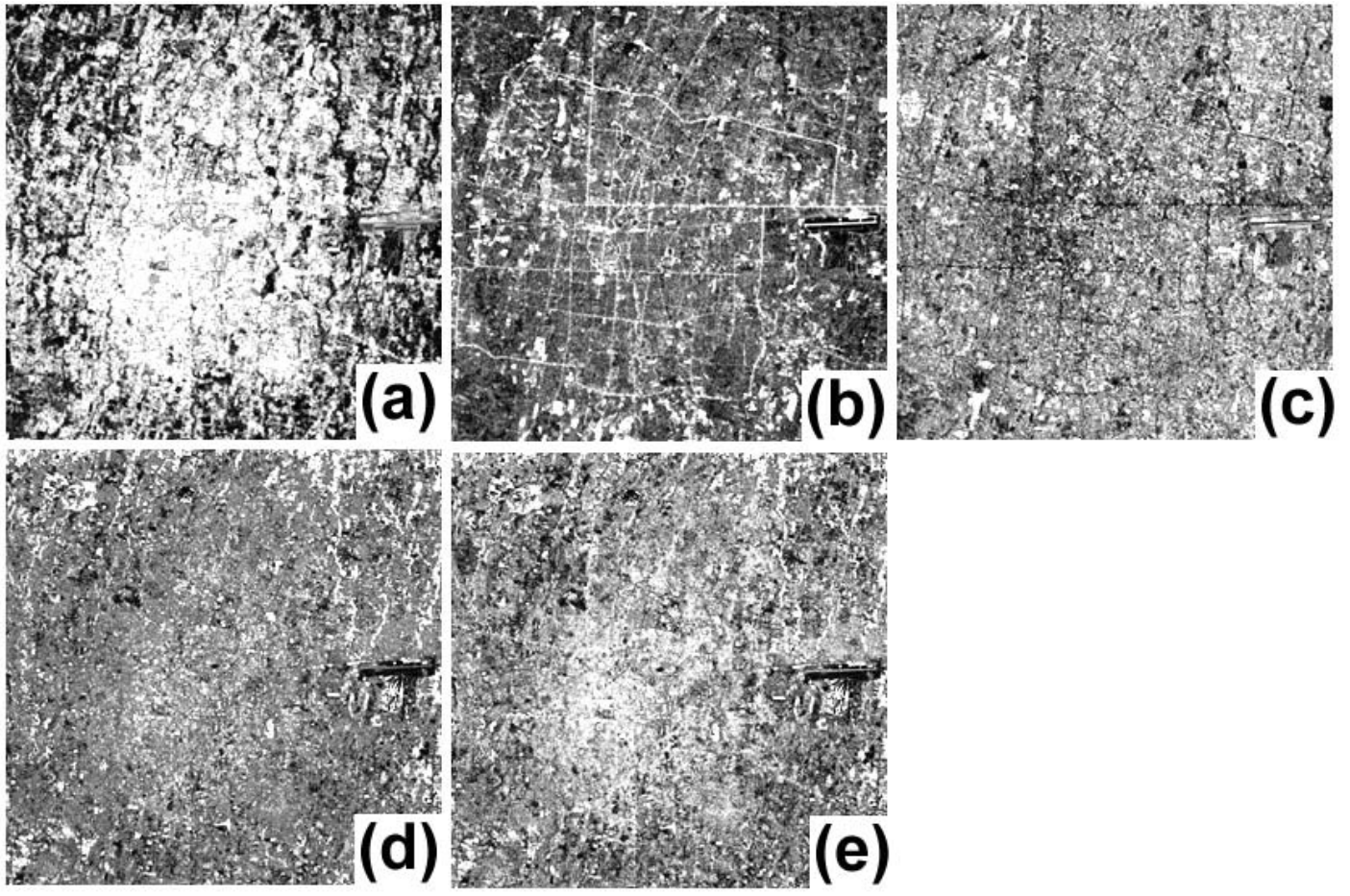

Figure 7. PCA Transformation Index for five thematic bands. (a) PC1, (b) PC2, (c) PC3, (d) PC4, (e) PC5.

\subsection{Normalized Difference Water Index}

Normalized Difference Water Index (NDWI) proposed by Gao (1996) uses a radiance or reflectance of the red band about $0.66 \mu \mathrm{m}$ and $0.86 \mu \mathrm{m}$ infrared band. Red band absorbs chlorophyll strongly, while the infrared band have very high vegetation reflections. The green band on the NDWI will maximise the water content while the near infrared band, which has a very high reflection of vegetation, 
is in control of minimising the water value. $\mathrm{Xu}$ (2006) introduce NDWI variance called MNDWI (Modified Normalized Difference Water Index) for urban, Middle Infrared (MIR) has better reflectance compared to another band. Therefore, when MIR is used instead of NIR for the index transformation, the built-up must have a negative value and give them a positive value for the water. Hence, the reflection value of the water will be seen more clearly and is not disturbed by the built-up reflection. The use of the normalised MIR band and green band formula will not disturb the vegetation reflection because the vegetation reflections will keep negative values. Equation 2 presents the NWDI formula by Gao (1996). While the MNDWI formula is provided in Equation 3 (Xu, 2006).

$$
\begin{aligned}
& \text { NDWI }=\frac{\text { Green-NIR }}{\text { Green+NIR }} \\
& \text { NMDWI }=\frac{\text { Green-MIR }}{\text { Green+MIR }}
\end{aligned}
$$

\subsection{Accuracy assessment (ground-truths)}

The collection of ground-truth data enables calibration of remote sensing data, and aids in the interpretation and data analysis. Groundtruth is also used for accuracy assessment of remote sensing imagery. Stratified random sampling was used in this field work method. Accuracy test is done by confusion matrix so it is known to be over accuracy, accuracy producer, and user accuracy. Confusion matrix is one assessment method for calculation of overall accuracy. A confusion matrix (or error matrix) is usually used as the quantitative method of characterising image classification accuracy. It is a table that shows correspondence between the classification result and a reference image (Exelesis Visual Information Solutions, 2014). This accuracy test process uses pure indices made from Landsat 8 OLI data by separating the appearance of built-up and non-built-up areas. The threshold value used to separate built-up automatically and non-built-up areas still use threshold zero and one. The usage of thresholds zero and one is selected to make it easier and ensure the land use is built-up area and nonbuilt-up areas.

\section{Results and Discussion}

\subsection{Index transformations}

Based on the results of the research, the combination of indices obtained from remote sensing imagery becomes an alternative solution for automatic data extraction, especially supported by the optimisation of the role of each band. The spectral band combination such as the reflection of vegetation, bare land, builtup land, and water supports the extraction of built-up land data in urban areas. Lack of NDBI as an index for built-up land extraction can be complemented by merging various indices that influence of land use. This study showed that the combination of Normalize difference built up index (NDBI) and Modified normalised difference water index (MNDWI) has the highest accuracy value.

The advantage of MNDWI is that it can differentiate soil and water (Figure 2). The index results in built-up area also show that the MIR spectral response is higher than NIR spectral response. Dry vegetation (low water content) has a higher reflection in the MIR wavelength. For that reason, the NDBI value for the appearance of dry vegetation is positive. The study also found that low-density vegetation areas had a positive NDBI value because soil reflections were more dominant than vegetation reflections. The water body, which has fairly high sediment content, also has a higher reflection in the MIR wavelength when compared to the NIR wavelength. Thus, shallow water reflections (with high sediment content) will be positive in NDBI transformation when using MIR and NIR wavelengths. Some of these difficulties lead to noise on the NDBI transformation automatically (Hidayati et al., 2017). It can be digitally seen that areas with low-density vegetation (dry vegetation) and water bodies (high sediment content) will have a positive value in NDBI so that it can beinterpreted as urban built-up area. This can disturb the result of index transformation and, hence, decrease the accuracy. Visually, dry vegetation and water bodies (high sediment content) have a grey scale. The combination of SAVI, MNDWI, with NDBI, will remove the disturbance of vegetation and water. The merging of these various indices is expected to improve the accuracy of the research. 

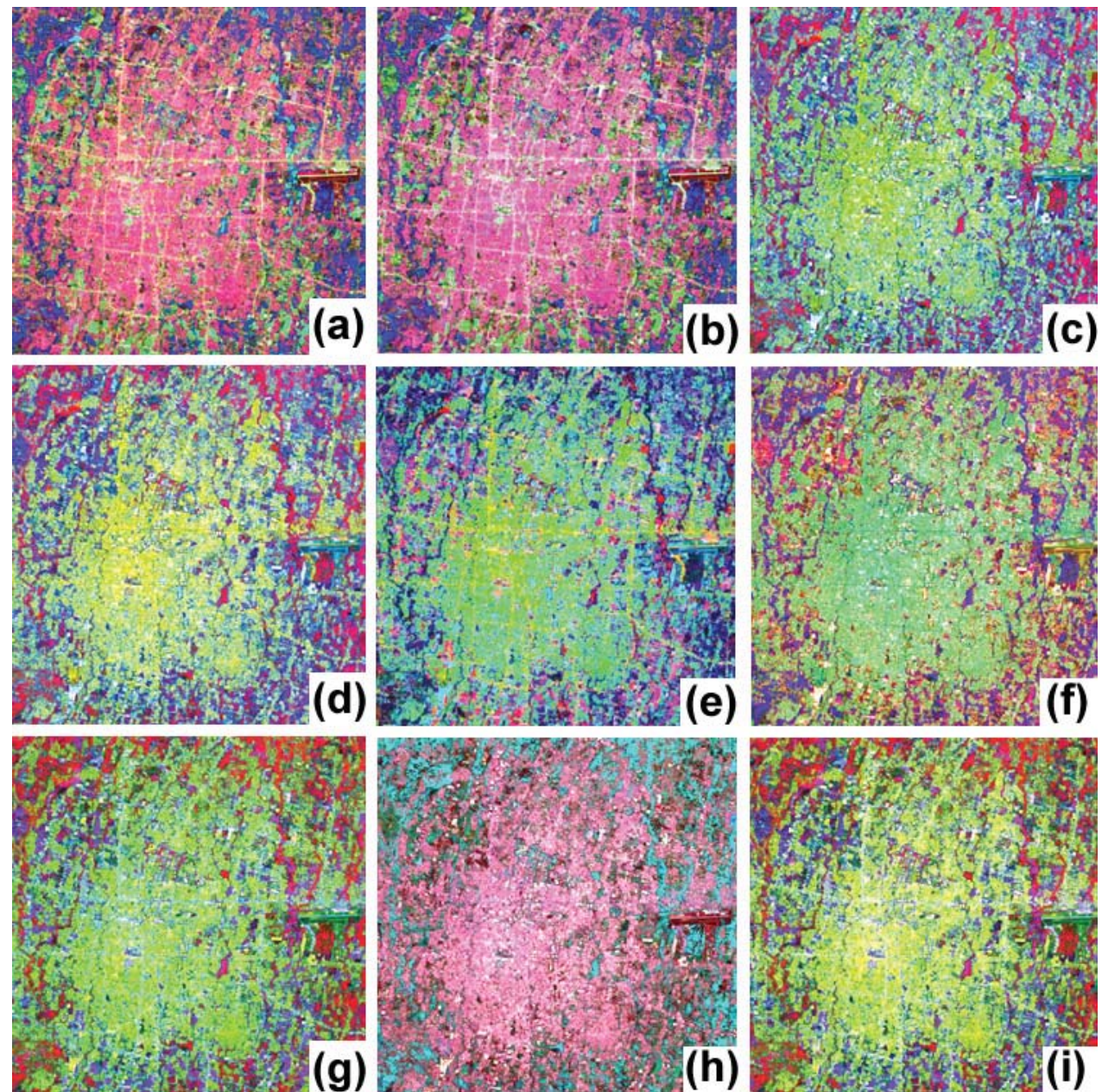

Figure 8. PC Composite based on Index Transformation. (a) PC Composite (124), (b) PC Composite (125), (c) PC Composite (134), (d) PC Composite (135), (e) PC Composite (213), (f) PC Composite (315), (g) PC Composite (412), (h) PC Composite (514), (i) PC Composite (512).

Table 4. Statistical values of five indices.

\begin{tabular}{ccccccc}
\hline Index & Min & Max & Mean & $\begin{array}{c}\text { Standard } \\
\text { deviation }\end{array}$ & Eigen value & Variance \\
\hline SAVI & -0.160537 & 0.135791 & -0.027509 & 0.021726 & 0.0354 & 0.147397 \\
NDWI & -0.254075 & 0.284196 & 0.080112 & 0.068824 & 0.008636 & 0.262343 \\
NDVI & -0.284196 & 0.254075 & -0.080112 & 0.068824 & 0.001037 & 0.262343 \\
NDBI & -0.711408 & 0.400302 & -0.13434 & 0.161281 & 0.000012 & 0.401598 \\
MNDWI & -0.688369 & 0.660321 & -0.268182 & 0.095536 & 0 & 0.309089 \\
\hline
\end{tabular}

NDBI and MNDWI are the best index combination for built-up area because the difference value between NDBI and MNDWI is the highest (Figure 3). The indices of SAVI, NDWI, and NDVI have the same contribution for index combination of built-up area identification. NDBI and MNDWI used middle infrared for their formula (Figure 4) showed that middle infrared has the highest reflectance for built-up land. The fact is also supported by the highest value of MIR standard deviation (Figure 5). Based on the results of index transformation, MNDWI has the maximum index value and highest dynamic range (Table 1). Meanwhile, the mean values of the indices are provided in Table 2. 
Table 5. Accuracy assessment of index value with fieldwork data.

\begin{tabular}{lcc}
\hline \multicolumn{1}{c}{ Combination index } & Overall accuracy (\%) & Kappa index \\
\hline NDBI & 85.72 & 0.71 \\
NDWI & 65.53 & 0.002843 \\
NDVI & 62.59 & 0.0028 \\
MNDWI & 45.84 & - \\
SAVI & 62.59 & 0.2854 \\
NDBI ${ }^{*} \mathrm{MNDWI}$ & 85.06 & 0.7959 \\
$\mathrm{NDBI}^{\mathrm{M} N D W I}$ & 90.30 & 0.8031 \\
$\mathrm{NDBI}^{\star} \mathrm{SAVI}{ }^{*} \mathrm{NDVI}{ }^{\star} \mathrm{MNDWI}^{\star} \mathrm{NDWI}$ & 74.15 & 0.4975 \\
$\mathrm{NDVI}^{\star} \mathrm{NDBI}$ & 74.81 & 0.5112 \\
$\mathrm{NDWI}^{\star} \mathrm{SAVI}$ & 46.56 & 0.001 \\
$\mathrm{NDVI}^{*} \mathrm{MNDWI}$ & 61.86 & 0.2705 \\
$\mathrm{SAVI}^{*} \mathrm{NDVI}{ }^{\star} \mathrm{NDBI}$ & 85.72 & 0.7186 \\
$\mathrm{NDBI}^{\star} \mathrm{SAVI}$ & 74.81 & 0.5112 \\
\hline
\end{tabular}
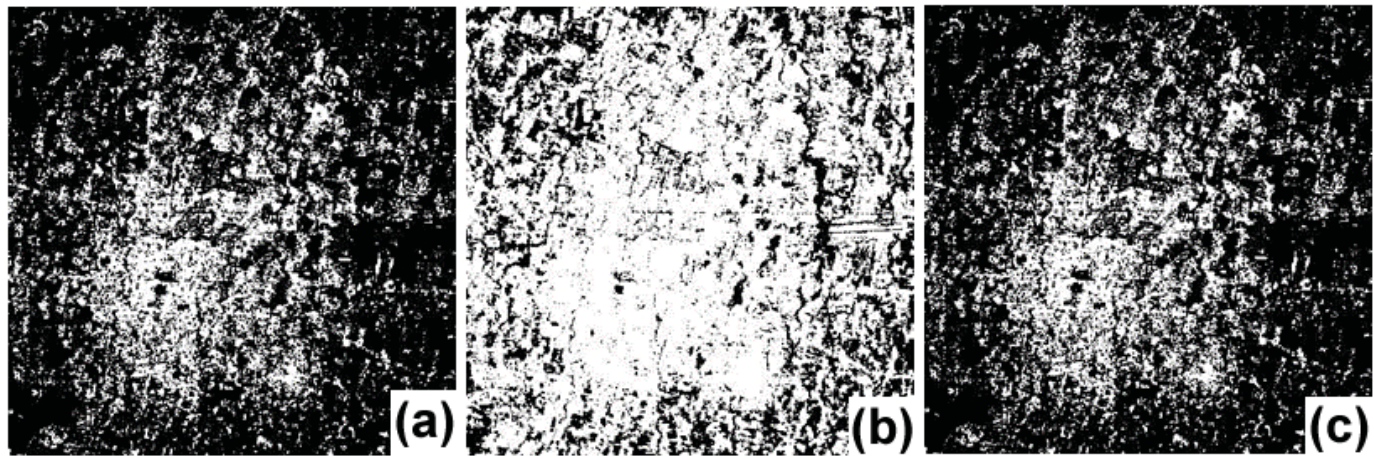

Figure 9. Extraction result of built-up land is that white colour is a built-up area and black colour is a non-built up area. (a) NDBI formula, (b) NDBI-MNDWI formula, (c) NDBI, NDVI, SAVI crosses mathematic combination.

\subsection{Built-Up extraction method}

The indices of NDVI, SAVI, MNDWI, NDBI, and NDVI have been done in the previous step on this research. The five indices used for making new index involving vegetation cover, water body, and soil reflections. The even multispectral bands from Landsat 8 OLI that have been reduced to five thematic bands showed a high correlation to each other (Table 3, also see Figure 6 for the scattergram plot based on index transformation). Their values are higher and better than seven band correlation of Landsat 8 OLI. Principle Component Analysis (PCA) will be used to combine five indices to find the best combination out of 20 index combination bands. PCA is a technique used to construct a new variable that is a linear combination of the original variable. The maximum number of these new variables is equal to the number of old variables, and these new variables are not correlated to each other. The first variable in the PCA corresponds to the maximum variance of the data used, the second variable represents the maximum variance not yet accounted in the first variable, and so on, until the new $\mathrm{z}$ variable shows the maximum variance not yet calculated in the previous $\mathrm{z}$ variable and the $\mathrm{z}$ new variable is not correlated.

Principle Component (PC) 1 showed that the urban phenomena and boundary are visibly clear (Figure 7). PC2 shows the urban utility network is more clearly visible when compared with other PC results. Each of the PCA results has a different role. Therefore, each channel resulting from PCA should not be ignored due to the selection of $P C$ results based on the research objectives. The urban visual PC 
composite results show specific characteristics for urban analysis. For example, PC composite results from a combination of $\mathrm{PC}$ band 315 and PC band 514 can be used to confine urban areas and see the urban as a whole. Visually, the composite PC band 125 is the optimal visual aspect for the urban, because the structure of the road and boundaries of urban settlements is clearly visible (Figure 8).

The development of the built-up land extraction method is based on each index impact (Table 4). In general, automatic extraction of built-up areas using NDBI resulted in an accuracy of $85.72 \%$, while the other four indexes had lower values than NDBI extraction (Table 5). Although MNDWI shows the smallest result for mapping accuracy, MNDWI results show information related to the road network and urban utility network is visually clearer when compared to other indexes. Figure 9 shows that the accuracy assessment result for NDBI and MNDWI reduction has the highest value for the accuracy test. The use of MNDWI and NDWI becomes very attractive especially for research areas dominated by rice fields and wetlands. This method should be tested in other areas with different characteristics.

\subsection{Discussion}

Information about spatial distribution is essential for city studies and also helpful to address some environmental problems. Built up area extraction becomes a fascinating subject to study (Hidayati et al., 2017; Li \& Chen, 2018; Luo et al., 2017; Varshney \& Rajesh, 2014; Xu, 2008)the modified normalized difference water index (MNDWI. Previous studies have applied various approaches, but limitations still exist, an issue which is addressed in this paper. Zha et al. (2003) conducted a pioneered research related to the built-up extraction using NDBI compared with manual interpretation. The NDBI accuracy was $92.6 \%$. The limitation of this research is the application of NDBI is unable to distinguish between urban and bare land area. Xu (2007) researched built-up extraction with several methods such as logic analysis, multispectral classification, and using PC for the combination of bands. The logic calculation is the best result compared to multispectral classification method or automatic extraction. The built-up data extraction research was also developed by Varshney \& Rajesh (2013) by creating a new index combination for the builtup land of Index-Based built up Index (IBI). Luo et al. (2017) found it was hard to separate the bare land areas from the built-up areas only by the built-up indices. Therefore, it needs further study to separate the bare land from the built-up needs.

This study tested a combination of several simple indices in urban areas such as NDBI, NDWI, MNDWI, NDVI, and SAVI to achieve the goal of improving mapping accuracy. The merger of indices produced 20 combinations of index multiplication with varying mapping accuracy (Table 5). Table 5 only displays results that have the logical existence of urban areas. The index combinations were partly omitted or unused because it has illogical results for urban data extraction. For example, the obtained results only produce 4 pixels representing urban areas. The highest accuracy result is combining NDBI and MNDWI. According to the mean and standard deviation values in Table 4, the highest value for built-up land is reflected in NDBI and the lowest value in MNDWI. After obtaining the selected index, for example, NDBI with the range of -1 to 1 , then NDBI is judged using pixel value $<0$ (less than 0 ) named non-built land, while pixel value $>0$ (more than 0) is a built-up land. The same rules and threshold are applied to other indices. The maximum accuracy in this study was obtained from NDBI-MNDWI reduction of $90.30 \%$. The result of the accuracy is higher when compared with NDBI extraction directly without involving another index. Multiplication of SAVI, NDVI, and NDBI has an accuracy of $85.72 \%$. However, this new study was tested only in the researched area, so it needs to be developed for other areas. Another weakness in this research is the range value of threshold using the general limit which is -1 to 0 and 0 to 1 , so other threshold value needs to be developed to optimise the mapping accuracy. 


\section{Conclusion and recommendation}

The extraction of urban built land can be automatically done with NDBI. However, the weakness of NDBI is that it cannot distinguish built up and bare land. Therefore it is necessary to develop the research by combining SAVI, MNDWI, NDWI, and NDVI. The merging of NDBI and MNDWI produced the highest accuracy of $90.30 \%$ either by multiplication (overlay) or reduction. Applications of SAVI, NDBI, and NDWI also give effect to urban builtup extraction and also have a high accuracy of $85.72 \%$. The recommendation from the study is to apply the method in areas with diverse vegetation, built-up areas close to rivers (water features), and rural areas. The threshold value in further research also needs to be developed to achieve optimum mapping accuracy.

\section{Acknowledgements}

The authors thank the Geography Doctorate Program that has provided an opportunity to take the courses. Thank you to the BPPDN who has funded this dissertation research. The authors also thank the Dean, Vice Deans, and all lecturers in Faculty of Geography, especially all lecturers in Geographic Information Science Department who were responsible for supporting my study.

\section{References}

Bagan, H., \& Yamagata, Y. (2012). Landsat analysis of urban growth: How Tokyo became the world's largest megacity during the last 40years. Remote Sensing of Environment, 127, 210 222. https:// doi.org/10.1016/j.rse.2012.09.011

Campbell, J. B., \& Wynne, R. H. (2011). Introduction to remote sensing. Guilford Press.

Caroline, A. H., \& Hidayati, I. N. (2016). Pemanfaatan Citra Quickbird dan SIG untuk Pemetaan Tingkat Kenyamanan Permukiman di Kecamatan Semarang Barat dan Kecamatan Semarang Utara. Majalah Geografi Indonesia, 30(1), 1-8.

Couturier, S., Ricárdez, M., Osorno, J., \& López-Martínez, R. (2011). Morpho-spatial extraction of urban nuclei in diffusely urbanized metropolitan areas. Landscape and Urban Planning, 101(4), 338-348. https:// doi.org/10.1016/j.landurbplan.2011.02.039

Deng, C., \& Wu, C. (2013). The use of single-date MODIS imagery for estimating large-scale urban impervious surface fraction with spectral mixture analysis and machine learning techniques. ISPRS Journal of Photogrammetry and Remote Sensing, 86, 100-110. https:// doi. org/10.1016/j.isprsjprs.2013.09.010

Exelesis Visual Information Solutions. (2014). ENVI Classic Tutorial : Classification Methods. In ENVI classic Tutorial (hal.1-26). North America. Diambil dari http:/ / www.harrisgeospatial. $\mathrm{com} /$ portals/0/pdfs/envi/Classification_Methods.pdf

Forzieri, G., Tanteri, L., Moser, G., \& Catani, F. (2013). Mapping natural and urban environments using airborne multi-sensor ADS40-MIVIS-LiDAR synergies. International Journal of Applied Earth Observation and Geoinformation, 23, 313-323. https:/ / doi.org/10.1016/j.jag.2012.10.004

Gao, B. (1996). NDWI - A Normalized Difference Water Index for Remote Sensing of Vegetation Liquid Water From Space. Remote Sensing of Environment, 266(April), 257-266.

Glenn, E. P., Huete, A. R., Nagler, P. L., \& Nelson, S. G. (2008). Relationship between remotelysensed vegetation indices, canopy attributes and plant physiological processes: What vegetation indices can and cannot tell us about the landscape. Sensors, 8(4), 2136-2160. https:// doi.org/10.3390/s8042136

Hai, P. M., \& Yamaguchi, Y. (2007). Characterizing the Urban Growth From 1975 To 2003 of Hanoi City Using Remote Sensing and a Spatial Metric. Forum Geografi, 21(2), 104-110.

He, C., Shi, P., Xie, D., \& Zhao, Y. (2010). Improving the normalized difference built- up index to map urban built-up areas using a semiautomatic segmentation approach. Remote Sensing 
Letters, 1(December 2010), 213-221. https:/ / doi.org/10.1080/01431161.2010.481681

Hidayati, I. N., Suharyadi, \& Danoedoro, P. (2017). Pemetaan Lahan Terbangun Perkotaan Menggunakan Pendekatan NDBI dan Segmentasi Semi-Automatik. In Prosiding Seminar Nasional Geografi UMS 2017, pp. 19-28.

Huete, A. (1988). A soil-adjusted vegetation index ( SAVI ). Remote Sensing of Environment, 25(March 2014), 295-309. https:// doi.org/10.1016/0034-4257(88)90106-X

Kaspersen, P., Fensholt, R., \& Drews, M. (2015). Using Landsat Vegetation Indices to Estimate Impervious Surface Fractions for European Cities. Remote Sensing, 7(6), 8224-8249. https:/ / doi.org/10.3390/rs70608224

Li, K., \& Chen, Y. (2018). A Genetic Algorithm-based urban cluster automatic threshold method by combining VIIRS DNB, NDVI, and NDBI to monitor urbanization. Remote Sensing, 10(2), 1-22. https:// doi.org/10.3390/rs10020277

Li, L., Lu, D., \& Kuang, W. (2016). Examining Urban Impervious Surface Distribution and Its Dynamic Change in Hangzhou Metropolis, 19-24. https:/ / doi.org/10.3390/rs8030265

Liu, T., \& Yang, X. (2013). Mapping vegetation in an urban area with stratified classification and multiple endmember spectral mixture analysis. Remote Sensing of Environment, 133, 251-264. https:/ / doi.org/10.1016/j.rse.2013.02.020

Luo, X., Peng, Y., \& Gao, Y. (2017). An Improved Optimal Segmentation Threshold Algorithm and Its Application in the Built-up Quick Mapping. Journal of the Indian Society of Remote Sensing, 45(6), 953-964. https://doi.org/10.1007/s12524-016-0656-4

McInerney, M., \& Lozar, R. (2007). Comparison of methodologies to derive a Normalized Difference Thermal Index (NDTI) from ATLAS imagery. American Society for Photogrammetry and Remote Sensing - ASPRS Annual Conference 2007: Identifying Geospatial Solutions, 1(Figure 1), 411-420.

Purwanto, A. (2015). Pemanfaatan Citra Landsat 8 Untuk Identifikasi Normalized Difference Vegetation Index ( Ndvi ) Di Kecamatan Silat Hilir Kabupaten Kapuas Hulu. Edukasi, 13(1), 27-36.

Sari, N. M., Chulafak, G. A., Zylshal, Z., \& Kushardono, D. (2017). The Relationship between the Mixed Pixel Spectral Value of Landsat 8 OLI Data and LAPAN Surveillance Aircraft (LSA) Aerial-Photo Data. Forum Geografi, 31(1), 83-98.

Suarez-rubio, M., Lookingbill, T. R., \& Elmore, A. J. (2012). Remote Sensing of Environment Exurban development derived from Landsat from 1986 to 2009 surrounding the District of Columbia , USA. Remote Sensing of Environment, 124, 360-370. https://doi.org/10.1016/j. rse.2012.03.029

Varshney, A., \& Rajesh, E. (2013). A Comparative Study of Built-up Index Approaches for Automated Extraction of Built-up Regions From Remote Sensing Data. Indian SocietyRemote Sensing, 42(3), 659-663. https:/ / doi.org/10.1007/s12524-013-0333-9

Varshney, A., \& Rajesh, E. (2014). A Comparative Study of Built-up Index Approaches for Automated Extraction of Built-up Regions From Remote Sensing Data. Journal of the Indian Society of Remote Sensing, 42(3), 659-663. https:/ / doi.org/10.1007/s12524-013-0333-9

$\mathrm{Xu}, \mathrm{H}$. (2006). Modification of Normalized Difference Water Index ( NDWI ) to Enhance Open Water Features in Remotely Sensed Imagery. International Journal of Remote Sensing, 27(No.14), 3025-3033. https:/ / doi.org/10.1080/01431160600589179

Xu, H. (2007). Extraction of Urban Built-up Land Features from Landsat Imagery Using a Thematic- oriented Index Combination Technique. Photogrammetric Engineering \& Remote Sensing, 73(12), 1381-1391. 
$\mathrm{Xu}, \mathrm{H}$. (2008). A new index for delineating built-up land features in satellite imagery. International Journal of Remote Sensing, 29(14), 4269-4276. https:/ / doi.org/10.1080/01431160802039957

Zha, Y., Gao, J., \& Ni, S. (2003). Use of normalized difference built-up index in automatically mapping urban areas from TM imagery. International Journal of Remote Sensing, 24(3), 583594. 